\title{
CES2 Gene
}

National Cancer Institute

\section{Source}

National Cancer Institute. CES2 Gene. NCI Thesaurus. Code C116037.

This gene is involved in xenobiotic detoxification. 